\title{
Learning English at Home: Young Children's Use of English Educational Media in South Korea
}

\author{
Sujeong Kang, Boram No, Nam Kyung Lee, and Naya Choi
}

\begin{abstract}
In recent years, interest in parent-guided English education for young children has been steadily rising in South Korea. The use of various types of media as a tool for English education at home has also been attracting increased notice. Based on past research findings regarding the impact of socioeconomic variables on the overall attainment of English education, the present study examined the use of English educational media at home by family capital in South Korea. A total of 1,802 cases from the third wave data of the Panel Study on Korean Children (PSKC) were used for analysis. The average age of the children was $\mathbf{2 6 . 2 5}$ months. Descriptive statistical analysis and logistic regression analysis were conducted. For financial capital, monthly income level did not have a significant effect on the use of English educational media at home. For human capital, mother's education level and age significantly affected the use of English educational media such as books and audio \& CDs; father's education level and age had an effect on the use of video \& DVDs for English education. For social capital, the rate of using English books and audio \& CDs at home was higher in suburban regions than in urban regions. This study is meaningful in that it examines the use of English educational media at home among young children, which has been rarely studied.
\end{abstract}

Index Terms-English education, media, young children, home, family capital.

\section{INTRODUCTION}

Learning English in East Asia has become more than merely the learning of a foreign language [1]. With English having been recognized as a basic skill for success, English proficiency in non-English speaking countries demonstrates potential in academic and professional domains and reflects a high level of socioeconomic background, enabling the provision of sufficient English education [2]. In other words, English has become a symbolic language that is directly connected with an individual's social status. As a result, parents in East Asian countries with high aspirations for their children's academic career invest heavily in English education from early childhood [3]-[5].

The phenomenon of Mommy English (ŏmmapho yŏngŏ), mother-guided English exposure at home, is currently garnering attention among parents of young children in South Korea. This teaching method encourages mothers to teach English directly to their young children at home, and allows mothers to create an English education environment by reading books, singing songs, watching videos or having

Manuscript received June 19, 2018; revised December 19, 2018.

The authors are with the Department of Child Development and Family Studies, Seoul National University, South Korea (corresponding author: Boram No; e-mail: hoy08@snu.ac.kr, borino@snu.ac.kr, njlee927@snu.ac.kr, choinaya@snu.ac.kr). simple conversations. Guidebooks and lectures are readily available as resources for mothers who are not fluent in English to practice Mommy English at home. A survey examining the types of educational tools used at the beginning of English education for 5-years-olds found that 9.4\% of these children had first learned English through Mommy English [6]. English education companies targeting young children are responding quickly to mothers' interests in Mommy English. Despite the mounting influence of "informal" English education such as Mommy English, research addressing this issue is rare.

The advantage of Mommy English is that it provides an English education environment at a lower cost than private institutes. In addition, English education can be carried out at home in which young children are given the chance to naturally practice English with their mothers who play a crucial role in children's language acquisition, rather than in an artificially manipulated educational environment. On the other hand, there is also a voice of concern about Mommy English. First, there is a question about the effectiveness of this method, since English education is provided by mothers who are not fluent in English. Also, increased interest in Mommy English is related to the mood of the Korean society, which burdens mothers with excessive responsibilities and roles for their children's education. English education in Korea is expressed as an "inter-generational gendered project" because mothers are overly responsible for the success of their children's English education [7].

Within an environmental context where English is not used daily, investigation of variables related to learning English in early childhood is scarce, and the research for English education in the home environment is even more at its beginning stages [1]. Studies, albeit limited, concerning English education at home for young children investigated the relationship between the home environment for English literacy and children's literacy development in Korea [8]-[10]. For example, one study showed that English literacy acquisition was influenced by mother's belief about the value of books and mother's language behavior while reading books [8]. However, existing studies have been confined to the subject of English books in the home environment as tools for English education. Nowadays, families have been generating educational environments through diverse media, which serves as an educational tool for supplying children with language input in English, especially in Korea where English is not used in daily life. This study aims to broaden the expanse of prior research to include the examination of media use in homes as English educational tools for young children.

Previous research has also shown that the English educational environment in East Asia differs by 
socioeconomic class [1], [4], [11], [12]. For young children in Korea where English is rarely used beyond the academic setting, more resources are required to receive an English education. Therefore, this study examines how media use for English education at home varies in relation to family capital. In particular, this study examines the effects of not only the background of mothers, but also those of fathers. Thus far, studies on English education for young children have mainly focused on mothers, but fathers should be considered as an important variable in the educational environment of the family.

\section{A. Theoretical Framework}

The theoretical background of this study is the social theory of family capital [13], [14]. This theory suggests that the family is a dynamic entity that conveys various forms of capital from the parent's generation to the children's generation for their educational attainment. In Coleman's theory, family capital consists of financial capital, human capital and social capital. These capitals influence children's education, and interactions among these capitals also affect children's academic achievement. For example, highly educated parents can provide academic assistance for their children. Families with abundant financial capital may have the capacity to acquire high-quality human resources. In this case, the possibility of accessing various educational and cultural resources also increases the benefits of social capital.

Financial capital is measured through the wealth and income of family members. This capital is the monetary sum that parents are able to invest in their children's education. However, sufficient financial capital does not necessarily guarantee a bountiful educational environment. How much parents choose to invest in their children's education may be more important than the availability of financial capital. For example, a study of Chinese families who had immigrated to Canada showed that these immigrant parents were actively financing their children's education despite economic difficulties [15].

Human capital refers to the level of knowledge and skills of family members. This capital can be measured by the educational background or occupation of family members. Even if all parents have equivalent levels of expectations for their children's academic achievement, parents differ in their ability to intervene in their child's language learning depending on the parent's educational background [15]-[17]. Oftentimes, mothers play an important role in constructing the language environment at home [7], [18], [19].

Social capital refers to the family and community resources available to the family. This capital includes both the social relationships existing in the family and the relationship between the family and the community [20]. Characteristics of the area in which a family resides interact with the family, thus affecting children's achievement.

\section{Methodology}

\section{A. Subjects}

This study used the third wave data set from the Panel Study on Korean Children (PSKC) surveyed in 2010. Of the
2,150 subjects surveyed, 1,802 cases were analyzed, excluding 348 cases who did not respond to questions regarding the use of English educational media at home. Children's ages ranged from 23 to 32 months, with an average age of 26.24 months. There were 918 boys, accounting for $50.9 \%$ of the total subjects in the survey panel.

\section{B. Measures}

Family capital was assessed by subcategorizing the capital into three parts: financial capital, human capital, and social capital. Financial capital was measured by the monthly household income reported by parents through open questions. Human capital was measured by age and educational background of each parent. Parental age was also measured by open-ended questions. Parents' education levels were coded as no schooling 1), elementary school 2), middle school 3), high school 4), vocational/technical college degree 5), university degree 6), Master's degree 7), and Ph.D. degree $8)$. Social capital was measured by the size of the community in which the family resided. Regional population size determined the categorization as urban, suburban or rural areas. This variable was converted into a dummy variable and was included in the model.

The use of English educational media at home was investigated using questionnaires that were completed by parents. Subjects were asked about the type of English educational media used at home, except for English educational media provided by institutes like kindergartens, day-care centers or regular English education classes offered by education companies. Multiple responses were made when reporting English educational media used at home. Media considered in this study included: 1) books, 2) TV programs, 3) audio \& CDs, 4) video \& DVDs, and 5) internet contents. English educational media was coded as 1 when the particular media type was used at home and 0 when it was not used.

\section{Statistical Analysis}

Statistical analyses were performed using SPSS 19.0 (IBM Co., Armonk, NY). Frequency analysis was conducted to identify the characteristics and the rate of media use. Logistic regression analysis was used to confirm whether family capital affected the use of English educational media at home.

\section{RESULTS}

\section{A. Types of English Educational Media Used at Home}

English educational media used at home were examined. First, 712 respondents $(33.1 \%)$ reported that they used more than one type of English educational media at home. The following are the results according to the type of media: 421 (23.4\%) used books, 199 (11.0\%) used TV programs, 417 (23.1\%) used audio \& CDs, 296 (16.4\%) used video \& DVDs and $51(2.8 \%)$ used internet contents. Books were the most commonly used English educational media at home, followed by audio \& CDs, video \& DVDs, TV programs, and internet contents.

\section{B. The Impact of Family Capital on the Use of Young}




\section{Children's English Educational Media}

\section{1) Use of English educational media}

The effect of family capital on the use of English educational media at home was examined. If one or more media type such as books, TV programs, audio \& CDs, video \& DVDs, or internet contents were used, it was coded as 1 . When none was used, it was coded as 0 . As a result, family capital had a significant effect on the use of English educational media at home $\left(\chi^{2}=34.43, p<.001\right)$. The Hosmer and Lemeshow test showed that there was an insignificant difference between the actual and predicted values of the dependent variable, and the model fit was acceptable $\left(\chi^{2}=3.96, p=.86\right)$.

Statistical significance of each independent variable was analyzed. As shown in Table I, mother's education level had a significant influence on the use of English educational media at home. Exp (B) of the mother's education level was 1.19, which implies that the probability of using English educational media increases by 1.19 times if the mother's education level increases by one unit. Mother's age was found to have a marginally significant influence $(p<.10)$. Exp (B) of the mother's age was .96, which implies that the probability of using English educational media decreases by 96 times, if the mother's age increases by one unit. Also, residential area had a marginally significant influence ( $p$ $<.10)$. Exp (B) of suburban vs. urban was 1.22, which implies that the probability of using English educational media increases by 1.22 times in the suburban areas as compared to urban areas.

TABLE I: INFLUENCE OF FAMILY CAPITAL ON THE USE OF ENGLISH EDUCATIONAL MEDIA AT HOME $(N=1,802)$

\begin{tabular}{|c|c|c|c|c|c|c|}
\hline & & B & S.E. & Wals & $p$ & Exp (B) \\
\hline (constant) & & -.13 & .60 & .05 & .83 & .88 \\
\hline $\begin{array}{l}\text { Financial } \\
\text { capital }\end{array}$ & $\begin{array}{l}\text { Household } \\
\text { monthly income }\end{array}$ & .00 & .00 & .80 & .37 & 1.00 \\
\hline \multirow{4}{*}{$\begin{array}{l}\text { Human } \\
\text { capital }\end{array}$} & $\begin{array}{l}\text { Father's } \\
\text { educational level }\end{array}$ & .10 & .07 & 2.17 & .14 & 1.11 \\
\hline & Father's age & -.02 & .02 & .87 & .35 & .98 \\
\hline & $\begin{array}{l}\text { Mother's } \\
\text { educational level }\end{array}$ & $.17^{\star}$ & .07 & 5.32 & .02 & 1.19 \\
\hline & Mother's age & -.04 & .02 & 3.19 & .07 & .96 \\
\hline \multirow[t]{2}{*}{$\begin{array}{l}\text { Social } \\
\text { capital }\end{array}$} & $\begin{array}{l}\text { Suburban vs. } \\
\text { urban }\end{array}$ & .20 & .12 & 2.84 & .09 & 1.22 \\
\hline & Rural vs. urban & .05 & .15 & .11 & .75 & 1.05 \\
\hline \multicolumn{2}{|c|}{-2 Log Likelihood } & \multicolumn{5}{|c|}{2023.74} \\
\hline \multicolumn{2}{|l|}{$\chi^{2}(d f=7)$} & \multicolumn{5}{|c|}{$34.43^{\star \star *}$} \\
\hline \multicolumn{2}{|c|}{$\mathrm{R}^{2}$ (Negelkerke) } & \multicolumn{5}{|c|}{.030} \\
\hline
\end{tabular}

Note.

$p^{*}<.05 \cdot p^{* * *}<.001$.

\section{2) Use of books}

We examined the effect of family capital on the use of books as English educational media at home. As shown in Table II, family capital had a significant effect on the use of books at home $\left(\chi^{2}=47.99, p<.001\right)$. The Hosmer and Lemeshow test showed that there was an insignificant difference between the actual and predicted values of the dependent variable, and the model fit was acceptable $\left(\chi^{2}=\right.$ $10.64, p=.22$ ).

Mother's education level, mother's age, and residential area were statistically significant variables. Exp (B) of the mother's education level was 1.39 , which implies that if the mother's education level increases by one unit, the probability of using books increases by 1.39 times. Exp (B) of the mother's age was .95 , which implies that the probability of using books decreases by .95 times if the mother's age increases by one unit. Exp (B) of suburban vs. urban was 1.31 , which implies that the probability of using English books for suburban area increases by 1.31 times as compared to urban areas.

TABLE II: INFLUENCE OF FAMILY CAPITAL ON THE USE OF BOOKS AS ENGLISH EDUCATIONAL MEDIA AT HOME $(N=1,802)$

\begin{tabular}{|c|c|c|c|c|c|c|}
\hline & & B & S.E. & Wals & $p$ & Exp (B) \\
\hline (constant) & & $-1.58^{*}$ & .70 & 5.12 & .02 & .21 \\
\hline $\begin{array}{l}\text { Financial } \\
\text { capital }\end{array}$ & $\begin{array}{l}\text { Household } \\
\text { monthly income }\end{array}$ & .00 & .00 & 2.33 & .14 & 1.00 \\
\hline \multirow{4}{*}{$\begin{array}{l}\text { Human } \\
\text { capital }\end{array}$} & $\begin{array}{l}\text { Father's } \\
\text { educational level }\end{array}$ & .07 & .08 & .77 & .38 & 1.07 \\
\hline & Father's age & -.01 & .02 & .09 & .76 & .99 \\
\hline & $\begin{array}{l}\text { Mother's } \\
\text { educational level }\end{array}$ & $.33^{* * *}$ & .09 & 14.36 & .00 & 1.39 \\
\hline & Mother's age & $-.05^{*}$ & .03 & 4.26 & .04 & .95 \\
\hline \multirow[t]{2}{*}{$\begin{array}{l}\text { Social } \\
\text { capital }\end{array}$} & $\begin{array}{ll}\text { Suburban } & \text { vs. } \\
\text { urban }\end{array}$ & $.27^{*}$ & .14 & 3.89 & .05 & 1.31 \\
\hline & Rural vs. urban & .02 & .18 & .01 & .91 & 1.02 \\
\hline \multicolumn{2}{|c|}{-2 Log Likelihood } & & & 1632.14 & & \\
\hline \multicolumn{2}{|c|}{$\chi^{2}(d f=7)$} & & & $47.99^{\star \star \star}$ & & \\
\hline \multicolumn{2}{|c|}{$\mathrm{R}^{2}$ (Negelkerke) } & & & .046 & & \\
\hline
\end{tabular}

Note.

$p^{*}<.05 . p^{* * *}<.001$.

\section{3) Use of TV programs}

Family capital did not have a significant effect on the use of TV programs as English educational media at home $\left(\chi^{2}=\right.$ $6.56, p=.48)$. Accordingly, the result table has been omitted.

\section{4) Use of audio and CDs}

We examined the effect of family capital on the use of audio \& CDs as English educational media at home. As shown in Table III, family capital had a significant effect on the use of audio \& CDs at home $\left(\chi^{2}=22.69, p<.01\right)$. The Hosmer and Lemeshow test showed that there was an insignificant difference between the actual and predicted values of the dependent variable, and the model fit was acceptable $\left(\chi^{2}=7.48, p=.49\right)$.

The education level of mothers and residential area were statistically significant variables. Exp (B) of the mother's education level was 1.26, which implies that if the mother's education level increases by one unit, the probability of using audio \& CDs increases by 1.26 times. Exp (B) of suburban vs. urban was 1.36 , which implies that the probability of using audio \& CDs increases by 1.36 times in suburban areas as compared to urban areas.

\section{5) Use of video and DVDs}

We examined the effect of family capital on the use of video \& DVDs as English educational media at home. As shown in Table IV, family capital had a significant effect on the use of video \& DVDs at home $\left(\chi^{2}=22.16, p<.01\right)$. The Hosmer and Lemeshow test showed that there was an insignificant difference between the actual and predicted values of the dependent variable, and the model fit was acceptable $\left(\chi^{2}=4.30, p=.83\right)$. 
TABLE III: INFLUENCE OF FAMILY CAPITAL ON THE USE OF AUDIO AND CDS AS ENGLish EduCATIONAL MEdia AT Home $(N=1,802)$

\begin{tabular}{|c|c|c|c|c|c|c|}
\hline & & B & S.E. & Wals & $p$ & $\begin{array}{l}\text { Exp } \\
\text { (B) }\end{array}$ \\
\hline (constant) & & $1.68^{*}$ & .70 & 5.80 & .02 & .19 \\
\hline $\begin{array}{l}\text { Financial } \\
\text { capital }\end{array}$ & $\begin{array}{l}\text { Household monthly } \\
\text { income }\end{array}$ & .00 & .00 & .08 & .77 & 1.00 \\
\hline \multirow{4}{*}{$\begin{array}{l}\text { Human } \\
\text { capital }\end{array}$} & $\begin{array}{l}\text { Father's } \\
\text { educational level }\end{array}$ & .04 & .08 & .25 & .62 & 1.04 \\
\hline & Father's age & .00 & .02 & .00 & .98 & 1.00 \\
\hline & $\begin{array}{l}\text { Mother's } \\
\text { educational level }\end{array}$ & $.23^{\star \star}$ & .09 & 7.10 & .01 & 1.26 \\
\hline & Mother's age & -.04 & .02 & 2.01 & .16 & .97 \\
\hline \multirow{2}{*}{$\begin{array}{l}\text { Social } \\
\text { capital }\end{array}$} & Suburban vs. urban & $.30^{*}$ & .14 & 4.91 & .03 & 1.36 \\
\hline & Rural vs. urban & .14 & .18 & .66 & .42 & 1.16 \\
\hline \multicolumn{2}{|c|}{-2 Log Likelihood } & \multicolumn{5}{|c|}{1636.28} \\
\hline \multicolumn{2}{|l|}{$\chi^{2}(d f=7)$} & \multicolumn{5}{|c|}{$22.69^{* *}$} \\
\hline \multicolumn{2}{|c|}{$\mathrm{R}^{2}$ (Negelkerke) } & \multicolumn{5}{|c|}{.022} \\
\hline \multicolumn{7}{|l|}{$\begin{array}{l}\text { Note. } \\
p^{*}<.05 .\end{array}$} \\
\hline
\end{tabular}

The father's age was a significant variable. Exp (B) of the father's age was .95 , which implies that if the father's age increases by one unit, the probability of using video \& DVDs decreases by .95 times. The father's education level was found to have a marginally significant influence $(p<.10)$. Exp (B) of the father's education level was 1.17, which implies that the probability of using video \& DVDs increases by 1.17 times if the father's education level increases by one unit.

TABLE IV: INFLUENCE OF FAMILY CAPITAL ON THE USE OF VIDEO AND DVDS AS ENGLISH EDUCATIONAL MEDIA AT HOME $(N=1,802)$

\begin{tabular}{|c|c|c|c|c|c|c|}
\hline & & $\overline{\mathrm{B}}$ & S.E. & Wals & $\overline{p p}$ & 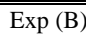 \\
\hline \multicolumn{2}{|l|}{ (constant) } & $-1.99^{*}$ & .81 & .00 & .01 & .14 \\
\hline $\begin{array}{l}\text { Financial } \\
\text { capital }\end{array}$ & $\begin{array}{l}\text { Household } \\
\text { monthly income }\end{array}$ & .00 & .00 & .60 & .44 & 1.00 \\
\hline \multirow{4}{*}{$\begin{array}{l}\text { Human } \\
\text { capital }\end{array}$} & $\begin{array}{l}\text { Father's } \\
\text { educational level }\end{array}$ & .16 & .09 & 2.84 & .09 & 1.17 \\
\hline & Father's age & $-.05^{\star}$ & .03 & 3.99 & .05 & .95 \\
\hline & $\begin{array}{l}\text { Mother's } \\
\text { educational level }\end{array}$ & .14 & 1.00 & 2.14 & .14 & 1.16 \\
\hline & Mother's age & .01 & .03 & .20 & .66 & 1.01 \\
\hline \multirow[t]{2}{*}{$\begin{array}{l}\text { Social } \\
\text { capital }\end{array}$} & $\begin{array}{ll}\text { Suburban vs. } \\
\text { urban }\end{array}$ & .18 & .16 & 1.28 & .26 & 1.20 \\
\hline & Rural vs. urban & -.00 & .21 & .00 & .99 & 1.00 \\
\hline \multicolumn{2}{|c|}{-2 Log Likelihood } & \multicolumn{5}{|c|}{1313.21} \\
\hline \multicolumn{2}{|l|}{$\chi^{2}(d f=7)$} & \multicolumn{5}{|c|}{$22.16^{\star \star}$} \\
\hline \multicolumn{2}{|c|}{$\mathrm{R}^{2}$ (Negelkerke) } & \multicolumn{5}{|c|}{.025} \\
\hline
\end{tabular}

\section{6) Use of internet contents}

Family capital did not have a significant effect on the use of internet contents as English educational media at home $\left(\chi^{2}\right.$ $=10.73, p=.15)$. Accordingly, the result table has been omitted.

\section{DISCUSSION}

The purpose of this study was to provide a national exploration of families' use of English educational media in relation to family capital for young children in South Korea. The use of media such as books, TV programs, audio \& CDs, video \& DVDs, and internet contents was analyzed.
With respect to financial capital, monthly income level did not have a significant effect on the use of English educational media at home. Results of the current study differ with findings from previous research which claim that income, perception of English education for early childhood, and investment in English education are interrelated in Korea [4], [11], [12] and in other East Asian countries [1]. Further research is needed, but a reason for this disparity may be due to the fact that media used for English education purposes can be provided at a lower cost compared to other types of English education services offered in the education market. On average, monthly fees for specialized English institutes of young children in Korea cost 1,240,000 won $(\$ 1,163)$ for full-day classes and 800,000 won (\$750) for half-day classes [21]. However, expenditures for media can be reduced by purchasing used books, sharing DVDs with other parents or using free internet contents.

For human capital, mother's education level significantly affected the use of English educational media such as books and audio \& CDs at home. In other words, the higher the mother's education level, the higher rate of using books and audio \& CDs. These results are consistent with Li's study [15], which reported that the academic background of parents significantly affected the possibility of active involvement in children's second language learning at home. Since the mother's knowledge and skills are required to provide English education at home, the mother's education level may influence the use of English educational media.

Also, mother's age made a statistically significant difference in the use of various types of educational media; specifically, there was a significant difference in the use of books. Findings that younger mothers use more English educational media at home suggest that these mothers may be more actively involved in English education for their children. According to a survey conducted in 2014, only $3.2 \%$ of high school students reported that they had begun their English education at age 3 , while $35.4 \%$ of 5-year-olds reported that they had begun learning English at age 3 [6]. That is, compared to the percentage of high school students who reported that they first began to learn English at age 3, the percentage of young English learners increased by more than ten times in the span of ten years. A study by Park [4] examined young children's English education through home visitations by English teachers. Results revealed that younger mothers had a tendency to begin English education for their children at an earlier age than older mothers in their 30's and 40 's. These findings suggest that younger mothers are more actively implementing English education for young children.

Interestingly, compared to the significant influence of mother's characteristics on the use of books and audio \& CDS, father's characteristics had a statistically significant influence on the use of video \& DVDs. Fathers who were younger or had higher levels of education were likely to use video \& DVDs as English educational media for their children at home. Further research is needed, but it is presumed that this result is due to the fact that video \& DVDs are more user-friendly for fathers compared to other types of educational media.

With respect to social capital, residential area had a significant influence on the use of English educational media, 
especially the use of books and audio \& CDs. That is, the rate of using English books and audio \& CDs at home was higher in suburban areas than in urban areas. There is little nationwide data available regarding the use of English educational media at home in South Korea, so there are limitations in interpreting these results. We can speculate, however, that parents in suburban areas may feel a stronger need for English education at home since the availability of educational services are limited in these areas as compared to larger metropolitan areas. To specify, English institutes for preschoolers are mainly located in urban areas such as Seoul (26.8\%) and Busan (14.5\%) [21]. Differences in the use of English educational media by residential areas should be considered for future research.

Family capital had no significant effect on the use of TV programs and internet contents in the current study. Since the average age of subjects was 26.25 months, there is a possibility that parents consider TV programs and internet contents as not yet suitable for young children. That is, children at this age may not have shown differences by family capital because the overall usage of TV programs and internet contents, in itself, was minimal. One research showed that children could not pay attention to TV programs and commercials until the age of 2 [22]. Another study using naturalistic observation reported that children began to intentionally watch the screen by 30 months [23]. In fact, only $199(11.0 \%)$ in this study reported the use of TV programs and $51(2.8 \%)$ reported the use of internet contents, which reflected the lowest rates of use by media type.

There are a few limitations in this study. Since there are other variables that can affect the English education environment in early childhood (e.g., parent's English experience and fluency), it is necessary to further refine family capital variables. In particular, forthcoming studies need to address the interaction of capitals, because financial, human and social capitals do not exist separately; they interact with one another to influence the educational environment [13]-[15]. Additionally, in recent years, a variety of educational media including A.I. speakers and E-readers have been utilized as educational tools, so new types of media and its effects should be included in future studies. This study was unable to reflect the present-day usage of media in Korea because the panel data surveying the topic of educational media was only collected in the 2010 dataset. Given the rapid development of media technology and its use, additional research based on more recent data is needed.

Despite these limitations, this study is meaningful in that it examined the execution of early childhood English education by parents at home, which was rarely discussed in the past. To the best of our knowledge, this is the earliest research on examining the use of young children's English educational media at home in Korea. Also, the sample of this study is considered to be a good representation of the population in Korea, since we used a nationwide, large-scale panel data.

\section{CONCLUSION}

This study examined the effect of family capital on the use of English educational media at home based on the social theory of family capital. Mother and father's education level, age and residential region affected the use of English educational media. This study is meaningful in that it examined English educational media use among young children in the home environment as guided by parents in South Korea, which has been rarely investigated.

\section{REFERENCES}

[1] Y. G. Butler, "Current issues in English education for young learners in East Asia," English Teaching, vol. 69, no. 4, pp. 3-25, 2014

[2] W. C. Zou and S. L. Zhang, "Family background and English learning at compulsory stage in Shanghai," English Language Education across Greater China, UL: Multilingual Matters, 2011, pp. 189-211.

[3] K.-S. Lee and S.-Y. Sohn, "A comparison of the daily lives of children in Korea, China, Japan and Taiwan," Journal of Early Childhood Education, vol. 32, no. 2, pp. 49-71, April 2012.

[4] S.-Y. Park, "An analysis of the current status of the early English education and parent's perception in Ulsan," M. S. thesis, Dept. English Education, Kyungnam Univ., Gyeongsangnam-do, Korea, 2014.

[5] H.-J. Jun, "English education for young children: A media discourse analysis," Journal of Early Childhood Education, vol. 31, no. 1, pp. 351-376, 2011

[6] Sa-gyo-yook Guk-jung Up-neun Sae-sang Man-deul-gi and Office of Rep. Eunhye Yoon, Nyun Seoul-Gyeonggi-ji-yuk Hak-bu-mo Deung 8,617 Myung Dae-sang Jo-gi-young-uh-gyo-yook Sil-tae In-sik-jo-sah Gyul-gwah-bo-do, 2014 Survey Report of 8,617 Parents' Perception of Early English Education in Seoul and Gyeonggi Province, 2014

[7] S.-J. Park and N. Abelmann, "Class and cosmopolitan striving: Mother's management of English education in South Korea," Anthropological Quarterly, vol. 77, pp. 645-672, 2004.

[8] M. S. Lee and M. S. Kim, “A study of factors influencing preschoolers' emergent English as a second language literacy skills: Maternal language behavior in picture book reading," Korean Journal of Child Studies, vol. 32, no. 6, pp. 157-185, 2011

[9] Y. M. Park, “(The) relationship between mothers' belief about reading and the home environment for English literacy and their children's interest in reading English books,” M. S. thesis, Dept. Early English Education, Yonsei Univ., Seoul, Korea, 2011

[10] J. Y. Moon, "The relationship of the mother's belief in reading and the English home literacy environment to the child's English vocabulary development," M. S. thesis, Dept. Early English Education, Yonsei Univ., Seoul, Korea, 2013.

[11] K.-H. Ban and H.-A. Seo, "A study of perception and actual fact for the early English language learning of the young children by the social and economical status of the preschooler's parents," The Journal of Humanities, vol. 14, no. 1, pp. 121-148, 2009.

[12] H. Y. Chun, H. A. Seo, S. H. Jwa, and M. S. Bae, "A study on current status of English education for toddlers and influential variables upon mother's demand," Journal of Korean Child Care and Education, vol. 7, no. 3, pp. 43-65. 2011.

[13] J. S. Coleman, "Social capital in the creation of human capital," American Journal of Sociology, vol. 94, pp. S95-S120. 1988.

[14] J. S. Coleman, Policy Perspectives: Parental Involvement in Education, US Department of Education. Washington DC, USA, 1991.

[15] G. Li, "Home environment and second-language acquisition: The important of family capital," British Journal of Sociology of Education, vol. 28, no. 3, pp. 285-299, 2007.

[16] V. Purcell-Gates, Other People'S Words: The Cycle of Low Literacy, Cambridge, MA: Harvard University Press, 1995.

[17] G. Li, "Perspectives on struggling English language learners: Case studies of two Chinese-Canadian children," Journal of Literacy Research, vol. 36, no. 1, pp. 29-70.

[18] R. L. Taylor, "Functional uses of reading and shared literacy activities in Icelandic homes: A monograph in family literacy," Reading Research Quarterly, vol. 30, no. 2, 194-219, 1995.

[19] T. L. Parcel and M. J. Dufur. "Capital at home and at school: Effects on student achievement," Social Forces, vol. 29, no. 3, pp. 881-912. 2001.

[20] L. Hao and M. Bonstead-Bruns. "Parent-child difference in educational expectations and the academic achievement of immigrant and native students," Sociology of Education, vol. 71, pp. 175-198. 1998

[21] J.-H. Kim, C.-H. Kim, S.-W. Park, S. H. Joo, K. H. Gu, S. W. Hwang, and S. B. Moon, "Analyzing on the State of Academic in Institute Management: Focusing on English Language Institutes for Pre-school 
children," Korean Educational Development Institute, Chungcheongbuk-do, Korea, 2015.

[22] K. Schmitt, K. D., Woolf, and D. R. Anderson, "Viewing behaviors by children and adults during television programs and commercials," Journal of Communication, vol. 53, pp. 265-281, 2003.

[23] D. R. Anderson and S. R. Levin, "Young children's attention to Sesame Street," Child Development, vol. 47, pp. 806-811, 1976.

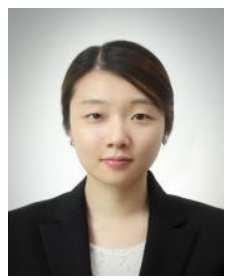

Sujeong Kang is studying for a doctoral degree in the the Department of Child Development and Family Studies at Seoul National University in Seoul, Korea. She received her bachelor's and master's degree in the Department of Child Development and Family Studies from Seoul National University. Her academic subjects of interest include language acquisition of children and educational medial.

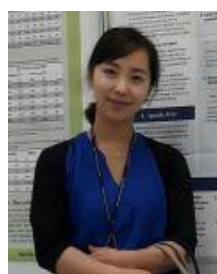

Boram No is studying for a doctoral degree in the Department of Child Development and Family Studies at Seoul National University in Seoul, Korea. She obtained her bachelor's and master's degree in the Department of Child Development and Family Studies from Seoul National University. She studies cognitive development of children and educational medial.

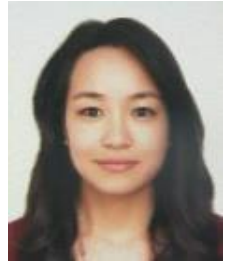

Nam Kyung Lee is currently pursuing a master's degree in the Department of Child Development and Family Studies at Seoul National University in Seoul, Korea. She obtained her bachelor's degree in the Department of Psychology with a minor in Applied Developmental Psychology from the University of California, LA, USA. Her academic interests include children's language and cognitive development.

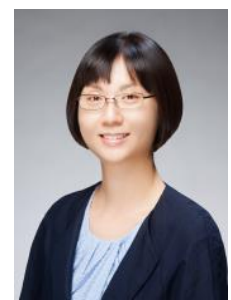

Naya Choi is an associate professor of the Department of Child Development of Child Development and Family Studies at Seoul National University in Seoul,

Korea. She received her bachelor's degree in the Department of Linguistics at Seoul National University, Korea. She received her master's and doctoral degree from the Department of Child Development and Family Studies at Seoul National University. She studies children's language, cognitive development and education. 